DOI https://doi.org/10.30525/978-9934-26-073-5-1-34

\title{
ПРИЕМ МНОГОГОЛОСЬЯ КАК ОСНОВА ПЕРСОНАЖНОЙ СИСТЕМЫ РОМАНА ОЛЬГИ ТОКАРЧУК «БЕГУНЫ»
}

\author{
Мохначева О. В. \\ кандидат филологических наук, \\ доиент кафедры перевода и славянской филологии \\ Криворожского государственного педагогического университета

\begin{abstract}
Белых Л. М.
студентка магистратуры

Криворожского государственного педагогического университета г. Кривой Рог, Днепропетровская область, Украина
\end{abstract}

В современных подходах к анализу художественного произведения «персонаж» рассматривается в системе субъектов текста («автор повествователь - рассказчик - герой» и др.). Некоторые современные исследователи центром художественного текста считают автора, расценивая персонажей как «релятивные, вторичные текстообразующие категории» [2]; в других случаях уровни проявления образа автора и персонажей в тексте понимаются как взаимодействующие равнозначные величины, способствующие его смысловой многозначности и полифонизму [1]. В парадигме «автор-текст-читатель», ключевой для постмодернизма, «замысел автора», по мысли Умберто Эко, не утрачивает значимости, так как уточняет «намерение текста» и направляет его интерпретацию.

Проблема соотношения голоса автора с голосами персонажей и их реализации в произведении является одной из самых актуальных в современной литературной науке в контексте исследования «формы «поведения» автора» [3, с. 3]. Сложная конструкция современного текста с программной установкой на «смерть автора» (Ролан Барт) предполагает множественность точек зрения, что делает произведение политональным, а голос автора реализуется в многоголосии персонажей.

В романах Ольги Токарчук многоголосие становится важным приемом расширения пространства текста. Некоторые критики обращали внимание на особенности проявления голоса автора и персонажей в романе «Бегуны» («Полеты»). Председатель жюри Международной Букеровской премии 2018 года писательница Л. Аппиньянези говорила: «Нам понравился голос повествования - он переходит от остроумия и 134 
радостного озорства к реальной эмоциональной структуре и обладает способностью очень быстро создавать характер, с интересными отступлениями и предположениями» [7]. Роль авторского голоса в построении смыслового пространства романа заметил и S. G. Bye: «Tokarczuk leads us from one voice to another, modulating tones and themes and at times building toward rich, poetic climaxes (Токарчук ведет нас от одного голоса к другому, модулируя тона и темы и временами приближаясь к богатым поэтическим кульминациям)» [6].

Роман «Бегуны» (2007) представляется художественным выражением позиции писательницы, обозначенной в ее Нобелевской лекции: «Наша реальность полнится голосами, ведущими речь от первого лица, так что на каждом шагу нас настигает этот многоголосый шум» [4]. В «Бегунах» Токарчук реализовала особенный многосюжетный тип повествования, «позволяющий нам видеть мир глазами чужого «я» и вслушиваться в окружающее от его имени» [Там же], и который демонстрирует неповторимую позицию рассказчика, переданную через многоголосый хор персонажей.

Роман состоит из 116 частей разного объема и жанровых характеристик, различных по теме и интонации повествования. Этой структурой обусловлена филигранно проработанная система персонажей, которая представлена главными, второстепенными, а также фоновыми персонажами. В центре этой сложной конструкции - главный персонаж «Я», который можно расценивать как авторский голос (согласно диалогической теории авторства М.Бахтина, где различается слово автора и «чужое слово»). Это образ повествовательницы с синдромом «персеверативной детоксикации» - недугом «обывательского характера», спровоцированного зависимостью от СМИ, - поиском смысла бытия в необычном, к тому же представленный в трех периодах ее взросления. Широкий интеллектуальный коллаж из фрагментов реальности, который демонстрирует этот голос, по сути является коллекцией моментальных снимков, наблюдений за «просчетами и осечками творения». Значимость этого голоса для художественной концепции «Бегунов» озвучен предельно точно: «Могу двигаться подобно привидению, заглядывать через плечо, подслушивать, как люди ссорятся, и наблюдать, как они спят, подложив под голову рюкзак, как разговаривают, не догадываясь о моем присутствии, только шевеля губами, формулируя слова, которые я собираюсь произнести от их имени» [5, с. 26].

С голосом повествовательницы сплетаются голоса второстепенных персонажей, рассказывающих свои отдельные истории: «внезапно 
оживившийся» голос молодого человека в черном элегантном плаще из поезда; «застенчивый и милый» голос человека, который брал с собой в служебные командировки книгу Чорана; «тревожный, напряженный» голос истории Куницкого, его жены, а также их сына; многозначные голоса женщины с разукрашенными хной руками, человека, который искал свои корни, человека в буфете, которой ни от чего не получал такого удовольствия, как от общения с оригиналом; Ясмины, приятной мусульманки; Эрика; путешественницы по имени Ингеборг («говорила так живо, с таким энтузиазмом»), подружки-поэтессы; Менчу, молодого обладателя, человека, который разводил ослов, доктора Бляу, Йозефины Золиман и ее отца, монахини Шариры, человека из Китая, Филиппа Ферпойена, Вилема Ван Горсена, Шарлотты, Аннушки, Джеймса Кука и многих других. Кроме них возникают и голоса фоновых персонажей, эпизодически появляющихся в историях для создания смысловой тональности текста или выражения оценки событий: например, во время поисков жены и ребенка Куницкого - нервные голоса полицейского и случайного помощника в поисках Бранко, а также «Звук протяжный, жалобный, словно голос какого-то зверя» [5, с.90]; «возбужденное шушуканье» подданных султана из истории Менчу; голос толпы очевидцев теракта: «Говорили мало, полушепотом» и пр.

Особенность многоголосья персонажей в романе «Бегуны» проявляется в том, что они не выполняют функцию хора античной трагедии, сопровождающего и оценивающего действие, а выступают как единый и разноплановый оркестр, в котором каждый голос, хотя и ведет свою партию, но в целом создает завершенный политональный текст. Такое оркестровое звучание многоголосья системы персонажей, сформулированное и произнесенное от их имени голосом главного повествователя, в романе «Бегуны» становится его материалом и характерной индивидуальной приметой творческой манеры Ольги Токарчук.

\section{Література:}

1. Бабенко Л.Г. Казарин Ю.В. Лингвистический анализ художественного текста. Теория и практика: учебник. Москва: Флинта: Наука, 2006. $496 \mathrm{c}$.

2. Гончарова Е.А. Пути лингвостилистического выражения категории автор-персонаж в художественном тексте. Томск: Изд-во ТГУ, 1984. $149 \mathrm{c}$.

3. Орлова Е.И. Образ автора в литературном произведении: учебное пособие. Москва: ФЛИНТА, 2021. 120 с. 
4. Токарчук О. Чуткий рассказчик: нобелевская лекция. 2019. URL: https://www.colta.ru/articles/literature/23214-olga-tokarchuk-nobelevskaya-lektsiya-polnyy-tekst (дата обращения: 8.04.2021).

5. Токарчук О. Бегуны / предисл. Э. Худобы; пер. с польского И. Адельгейм. Москва: Новое литературное обозрение, 2010. 404 с.

6. Bye S. G. Flights by Olga Tokarczuk. Book Reviews. 2018. URL: https:// www.worldliteraturetoday.org/2018/july/flights-olga-tokarczuk (дата обращения: 18.04.2021).

7. Flood A. Olga Tokarczuk's 'extraordinary' Flights wins Man Booker International prize. 2018. URL: https://www.theguardian.com/books/ 2018/may/22/ olga -tokarczuk -flights-wins-man-booker-international-prizepolish (дата обращения: 19.04.2021).

DOI https://doi.org/10.30525/978-9934-26-073-5-1-35

\title{
СИМВОЛІКА ГЕРОЇЧНОГО В УКРАЇНСЬКІЙ НАРОДНІЙ ДУМІ «ІВАН КОНОВЧЕНКО»
}

\author{
Набок М. М. \\ кандидат філологічних наук, \\ дочент кафедри мовної підготовки іноземних громадян \\ Сумського державного університету \\ м. Суми, Украӥна
}

Етимологія слова «символ» бере початок від грецького іменника unmbolon, що означає 'знак', 'прикмета', а дієслово з таким же коренем у перекладі означає «з'єднувати, зіштовхувати, порівнювати» [2, с. 738]. Символіка, як поняття етногенетичне, у фольклорних творах допомагає нам зрозуміти спосіб мислення наших пращурів, їх моральні, духовні, етичні й естетичні ідеали. В основу змісту категорії «героїчне» покладено принцип співвідношення реальності та ідеалу [3]. Українському народу властиве мужнє сприйняття життя, що синтезувало у собі внутрішню гармонію і героїчний дух. Відчуття спільної волі, належності до окремої нації із спільними віруваннями, традиціями, думками виражено в ідеї патріотизму, вшанування предків, слави.

У думі «Іван Коновченко», образ Cтепу постає як чинник «селекції» [5, с. 55]. Суспільство, яке пасивно спостерігало та визискувало перед ворогом, передавало таку ж модель поведінки своїм нащадкам, активна ж частина народу чинила опір та гинула в боях. У всіх варіантах думи «Іван 